УДК 821.14’02(94)(091)

https://doi.org/10.18485/godisnjak.2016.11.1

Томислав Ж. Јовановић*

Оригинални научни рад

Филолошки факултет

Примљен: 05. 10. 2016.

Универзитет у Београду

Прихваћен: 20. 10. 2016.

\title{
СЛОВО О НИЋИФОРУ ФОКИ И О КРЧМАРИЦИ ТЕОФАНИ
}

У овом раду говори се о приповеци посвећеној трагичном крају цара Нићифора Фоке, кога је убио Јован Цимиски, а помогла му у томе царица Теофана. Историјске чињенице имају о том догађају своју верзију збивања, а приповетка у великој мери мења њихов смисао, будући да у њој постоје фолклорни наноси обогаћени легендарним призвуком казивања. Најупечатљивији је Теофанин лик, која је била кћи крчмарице. Приповетка је написана на грчком језику крајем XII - почетком XIII века и преведена је на словенски. Сачуване су две варијанте, дужа и краћа. Српски преписи познају обе варијанте. Њихов текст приређен је уз праћење осталих преписа.

Кључне речи: цар Фока, Теофана, убиство, српски преписи, издање текста.

Византијски цар Нићифор II Фока владао је од 963. до 969. године. Његову владавину окончао је насилно Јован Цимискије и наследио га на престолу погубљењем, за које се сматра да је потпомогнуто Фокином супругом Теофаном ${ }^{1}$. Овај догађај описан је у грчким летописним и историографским делима Лава Ђакона, Михаила Псела, Јована Скилице и Јована Зонаре. На књижевном пољу појавила се повест крајем XII - почетком

*tomjovan1@gmail.com

${ }^{1}$ П: Сырку, Византійская повъсть объ убіеніи императора Никифора Фоки въ стариномъ болгарскомъ пересказъ, Санктпетербургъ 1883; И. Ђурић, Породица Фока, Зборник радова Византолошког института, XVII, Београд 1976, 189-296; Б. Крсмановић, Д. Џелебџић, Јован Цимискије и Нићифор II Фока: позадина и мотиви једног убиства с предумишљајем, Зборник радова Византолошког института, XLVII, 2010, 83-120. 
XIII века на грчком језику која на литераран начин сагледава убиство цара Фоке. ${ }^{2}$ То дело одступа умногоме од историјске подлоге, али, својствено књижевном уобличавању, маштовитом имагинацијом уводи чиниоце који га приближавају сижеима фолклорне нарације.

Лик цара Нићифора Фоке близак је аскетском типу владара који се својим односом према браку и жени, начину спавања на камењу „оштром као нож” и непрестаном појању псалтира уз мољење Богу приближава монашком лику. Иако је историјски цар Фока имао једног брата, у овој повести њих је било осморица, тако да мотив деветоро браће улази у митолошки круг бројева који почивају на укорењеним фолклорним обрасцима стваралаштва. То се очитује већ у сцени у којој су цару Фоки дошли бољари, кнезови, војници и патријарси да га моле да се жени. Он им је обећао да ће им испунити жељено, али им је попут модела неких бајки ставио до знања да ће се оженити оном којој буде одговарала обућа (калиге) коју је дао да се направи изузетно мале величине и веома тесна. Тиме је Фока намеравао да отклони могућност да ће се пронаћи особа са тако малим стопалима. Начин трагања за одговарајућом девојком такође има призвук мотива потеклог из бајке. Иако је на Фокино изненађење пронађена девојчица којој је пристајала неочекивана обућа, цар је одржао обећање и оженио се. Царевом одлагању да ступи у брачни однос одговарао је, макар за извесно време, узраст девојчице која још није стасала да постане жена. Пошто се цар венчао са њом због људи, остао је доследан у свом односу према њој, јер је се није дотицао. Њено далеко ниже порекло од царског, јер је била кћи крчмарице, унело је додатан подстрек да се њен карактер испољи касније као проблематичан и лакши за осуду.

Царево избегавање телесне блискости са супругом Теофаном трајало је све док она није довољно одрасла и њена красота била веома велика, када је једног дана своју зрелост исказала на речит и поетичан начин. Блиско симболици старозаветне Песме над песмама, Теофана осликава своју набујалу младост и спремност да се сједини са мужем: „Господару, јабуке твоје доспеле су и трешње твоје узреле су и време ти је да их бе-

${ }^{2}$ К. Мечев, Възмездие за жестокостта: Към въпроса за идейната характеристика и времепоявата на средневековния български апокрифен разказ за убийството на византийския император Никифор Фока от кръчмарката Теофана, Литературна мисьл, 2. София 1975, 115-136; É. Turdeanu, Le dit de l'empereur Nicéphore II Phocas et de son épouse Théophano, Thessalonique 1976; М. А. Салмина, Повесть о Никифоре Фоке, Словарь книжников и книжности Древней Руси, вып. II (вторая половина XIV-XVI в.), часть 2, Л-Я, АН СССР, Институт Русской литературы (Пушкинский дом), „Наука”, Ленинград 1989, 255-256; А. Милтенова, Кръчмарката Теофана, Старобългарска литература. Енциклопедичен речник, „Петър Берон”, София 1992, 245-246. 
реш.” Чувајући своју намеру да буде чедан и у новим околностима, када је Теофана стасала да буде жена, цар јој је саопштио потпуно неочекивану замисао:

Ућути, ућути, Теофано, сачекај мало док не одем у Јерусалим и поклоним се за тебе и за себе. Када дођем, учинићу себе игуманом и тебе игуманијом и спасићемо душе наше, а потом шта нам буде ${ }^{3}$ (Стара српска књижевност. Хрестоматија, 2000: 412).

На овакво царево одлучно одбијање да се телесно зближи са Теофаном царица је спремила освету која ју је најпре одвела другом мушкарцу. Изабрала је царевог велможу Цимискија, који је био у великој части. Њено убеђивање да Цимискија одведе у своје тајне одаје и да се слегне са њим наишло је на његово одбијање. Увођењем мотива женске омађијаности Теофана је постигла жељено чешћим одлажењем Цимискију, а он је, као из сна пренувши се, схватио шта се догодило и да је тиме издао свог цара, о чему говоре и његове речи кајања: „О, тешко мени, куда денух себе и Теофану!” Да ово није било све што је Теофана желела, њено убеђивање Цимискија да погуби цара Фоку достигло је градациони врхунац. Уза све негодовање и одупирање Цимискија да не жели тако нешто да учини, у њему је настао преокрет када му је Теофана обећала да ће га учинити царем.

Грађена на контрастима, пре свега ликова, а онда и сцена у којима се очитују сучељавања, ова повест казује о царевом погубљењу такође кроз принцип супротности. У тренутку када Теофана тајно уводи Цимискија у цареву одају у намери да га погуби, присутна је доследност испољена у царевој навици да седи над Псалтиром читајући га. На другој страни јавља се кратак опис царевог мача са особинама преузетим из народне традиције, јер он плива кроз метал „као кроз воду”. Такав мач у рукама Цимискија лако је посекао царев врат. Са друге стране, испуштени Псалтир из царевих руку погодио је Цимискија у главу и догађа се скоро истовремена смрт обојице - и цара и његовог убице.

Даљи ток повести после оваквог царевог окончања водио је ка Теофанином испуњењу замисли да читав догађај прикаже као својевољан царев одлазак са двора на далек пут у Јерусалим заједно са својом браћом

${ }^{3}$ У препису старе збирке Народне библиотеке у Београду број 104 одговор цара Фоке Теофани нешто је развијенији и у преводу гласи: „Теофано, то што би било међу нама, била би саблазан за свет. Него, стрпи се мало а ја ћу поћи у Јерусалим и поклонићу се за мене и за тебе. И када се вратим, учинићу те у једном манастиру игуманијом, а ја ћу бити у другом манастиру, и душе наше спасићемо." (Хрестоматија средюовековне књижевности, том I, 2012: 294). 
и Цимискијем. Да би убедила поданике у такво уверење, она је царево тело сакрила уз помоћ две девојке слушкиње у дубоку јаму која се налазила на скровитом месту у двору. Цимискијево тело сакрила је на друго место. Лукавством је намамила исте ноћи појединачно и свих осморо цареве браће и гурнула их у исту јаму погубивши их. Да би све изгледало убедљивије, Теофана је до зоре нашла другог мужа и учинила га царем. Њеном мало вероватном убеђивању и приказивању изненадно промењеног стања на двору ипак су поверовали и покренули се по копну и по мору да траже свог цара. На велико разочарење што га нису нашли, приморали су Теофану да каже истину о свему. Иако је са упорношћу одбијала да призна шта је учинила, једна од двеју девојака које су јој помагале да скрије царево тело и да погуби његову браћу, одала ју је, а казна је била сурова - њена утроба расточена је по граду.

У краћој варијанти повест се окончава тиме што се проналази царево тело са телом браће и увића се да су она постала света. Поједине верзије ове варијанте у једној реченици указују на погубност злих жена: „Видите ли, браћо, какве мужеве жене погубе?”4 Дужа варијанта препознатљива је по свом завршетку, који доноси придику о злим женама: „Видите ли, браћо, како пет жена погубише пет мужева? Теофана цара Фоку и његових деветоро браће, Ева Адама из раја изведе и погуби, [Далида] прелашћу Самсона, цара Давида сузама из ума изведе и погуби, и Велзавеља пророка Илију по свету гоњаше, Иродијада Јована Крститеља погуби ради прљавог смешања."5 Овакво окончање повести по свој прилици преузето је из засебног списа посвећеног злим женама, који се јавља у низу варијанти и преписа током средњег века (Каган 1989: 399-401; Милтенова 1994: 28/29; 131-136).

Повест је преведена на словенски језик и позната је у две варијанте у бугарским, српским и руским преписима са жанровским одређењем у наслову као слово. Најстарији сачувани српски препис прве, краће, варијанте потиче из XIV века и налазио се у старој збирци Народне библиотеке у Београду, изгорелој у немачком бомбардовању 1941. године, под бројем 104 (на странама 48a-49б, у даљем спомињању користимо скраћеницу Сп) $)^{6}$. Из XV века постоји српски препис који се налази у рукописној збирци Народне библиотеке „Свети Кирил и Методиј” у Софији са сигнатуром

\footnotetext{
${ }^{4}$ Према препису старе збирке Народне библиотеке у Београду број 104.

${ }^{5}$ Према препису рукописне збирке Патријаршијске библиотеке у Београду број 343.

${ }^{6}$ Издање Слова у: М. Сперанскій, Замътки о рукописяхъ Белградскихъ и Софійской библіотекъ, Извъстія Историко-филологическаго Института князя Безбородко въ Нъжинъ, XVI, Москва 1898, 57-59; Превод овог преписа у: Стара српска књижевност. Хрестоматија, 411-414; Хрестоматија средњовековне књижевности, том I, 293-296.
} 


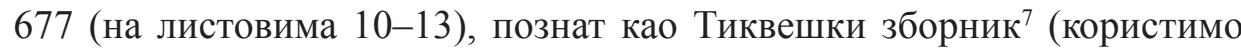
скраћеницу На). У манастиру Никољцу у Црној Гори чува се рукопис са преписом Слова под бројем 82 и исписан је у периоду 1515/1520. године (на страницама 66б-70б, користимо скраћеницу Н). Из XVI века потиче српски препис који се налази у рукописној збирци Хрватске академије знаности и умјетности у Загребу са сигнатуром III а 10 (на страницама 37a-39a).

Другој, нешто дужој, варијанти припада препис из збирке Патријаршијске библиотеке у Београду са сигнатуром 343 , који потиче из последње четвртине XVII века (на страницама 451a-454a). Близак овој варијанти јесте препис са примесама бугаризама из XVII века из рукописне збирке Народне библиотеке „Свети Кирил и Методиј” у Софији са сигнатуром 326 (на страницама 126б-128б).

Осврћући се на најстарији текст повести, који се налазио у изгорелој збирци Народне библиотеке у Београду, Михаил Сперански указао је на одлике архаичнијег лексичког слоја који се више очувао него у млађим преписима, чиме се могао одликовати првобитни текст превода или прераде (Сперански 1898: Замътки, 49). Бавећи се овим Словом, М. Сперански је имао могућност да користи издања два словенска преписа, једног бугарског ${ }^{8}$ и другог српског ${ }^{9}$. Овом приликом разматрамо српске преписе, који на очигледан начин показују знатну разноликост, настајалу у различитим срединама, временима и потеклих од различитих писара, што се може уочити поређењем наведених преписа.

Иако првој верзији припадају четири српска преписа, међу њима запажају се мање или веће разлике. То се нарочито испољава у разликама које су видљиве између Сп са једне стране и Н, На са друге стране ${ }^{10}$. Већ испод самог наслова једино Сп има уобичајену формулу Благослови, оче,

${ }^{7}$ Издање овог зборника заједно са повешћу: Н. А. Начовъ, Тиквешки рхкописъ, Сборникъ за народни умотворения, наука и книжнина, VIII, София 1892. Превод овог преписа у: Из старе српске кьижевности. Превео и саставио Миливоје М. Башић. Четврто, исправљено и нешто допуњено, издање. Београд, Издавачка књижарница Геце Кона, 1931, 43-46; Из наше књижевности феудалног доба. Друго допуњено издање. Избор, редакција, превод и коментари Драгољуб Павловић и Радмила Маринковић. Предговор Драгољуб Павловић. Сарајево, „Свјетлост”, 1959 [Треће и четврто издање: Београд, „Просвета”, 1975. Библиотека Просвета, књига 102], 203-205.

${ }^{8}$ Препис из рукописа Библиотеке Румунске академије наука број 740: П. Сырку, Византійская повъсть, 111-113.

${ }^{9}$ Препис у Тиквешком зборнику у Народној библиотеци „Кирил и Методиј” у Софији број 677: Н. А. Начовъ, Тиквешки рккописъ, 8-9.

${ }^{10}$ Овом приликом нисмо имали могућност да у поређења укључимо и препис збирке ХАЗУ број III а 10. 
за тражење благослова пред читање наглас присутнима. Почетак Слова нешто је проширенији у Сп и блискији древним саставима који временску удаљеност од актуелне садашњости смештају у неизмерну давнину. Док Н и На имају једноставнији приступ почетној нарацији речима „Беше цар Фока”, Сп попут бајки уводи препознатљив образац „У она времена беше цар Фока”. Лексичка решења у сва три преписа у знатној мери подударна су, али понекад она се крећу у кругу синонима. Тако се уочава већа лексичка разлика коју носи На наспрам Н. У напоредном исказивању то изгледа овако:

\begin{tabular}{|c|c|c|c|}
\hline $\mathrm{H}$ & $\mathrm{Ha}$ & $\mathrm{H}$ & Сп \\
\hline HАEЖE & ГA' & Бона C€ & OүБО⿴囗丨 CE \\
\hline ннћщн вЊџьмїн & ZАОБОМЬ & вьร'Мьшє & Поєщшшє \\
\hline БА(A)го & 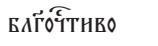 & прндог & вьzвращоү сє \\
\hline СьБраш $(\epsilon)$ с $\epsilon$ & ПрНБра сє & Красєџї̈ сє & оүкраснвшн сє \\
\hline вьร̆'Мьшє & ПрнєМшє & сковЂрсми(ь) & цОАЕМЬ \\
\hline прїнцєсї сє & пргітн сє & БА(а)говханїє & (во)нга Бйговханнга \\
\hline ФБнчан & HaOr & БА(а)говханїє & вонга \\
\hline ґаБлькїн & ГаБлани & ц(а)рнграА(b) & $\Gamma \rho \mathrm{A}(\Delta \mathrm{b})$ \\
\hline прндог & вьzврачог сє & $\omega т[\mathrm{~L}] в \rho ь z о ш \epsilon$ & б̈крыхог \\
\hline Ү(ь)стїн & Мर्Tн & & \\
\hline СЬMECH СE & СЬАЕЖЕЕ Сє & & \\
\hline вьZьБНОҮВЬ & вьСПрєн४в сє & & \\
\hline НАБжє & ГAE & & \\
\hline ЖЕАєZО & MTь & & \\
\hline сь弓адаїн & $\hat{\omega}$ Zадн & & \\
\hline рась'те & прБсєче & & \\
\hline zакована & zакопана & & \\
\hline посла & по्रттн & & \\
\hline СЬБраШє Сє & ПрнБрашє сє & & \\
\hline сАьшнте & послоүшанте & & \\
\hline Послаше & п४стншє (сє) & & \\
\hline (ББрьтошє & вндћшє & & \\
\hline
\end{tabular}


Далеко већа неподударност лежи у лексички и садржајно другачијем обликовању читавих делова Слова у Н и Сп. На основу таквог стања може се говорити пре о знатној преради из каснијег времена, а не о новом преводу. Као да се том приликом ишло на сижејно сажимање, чиме се губило на детаљима, што се уочава у следећим случајевима неслагања:

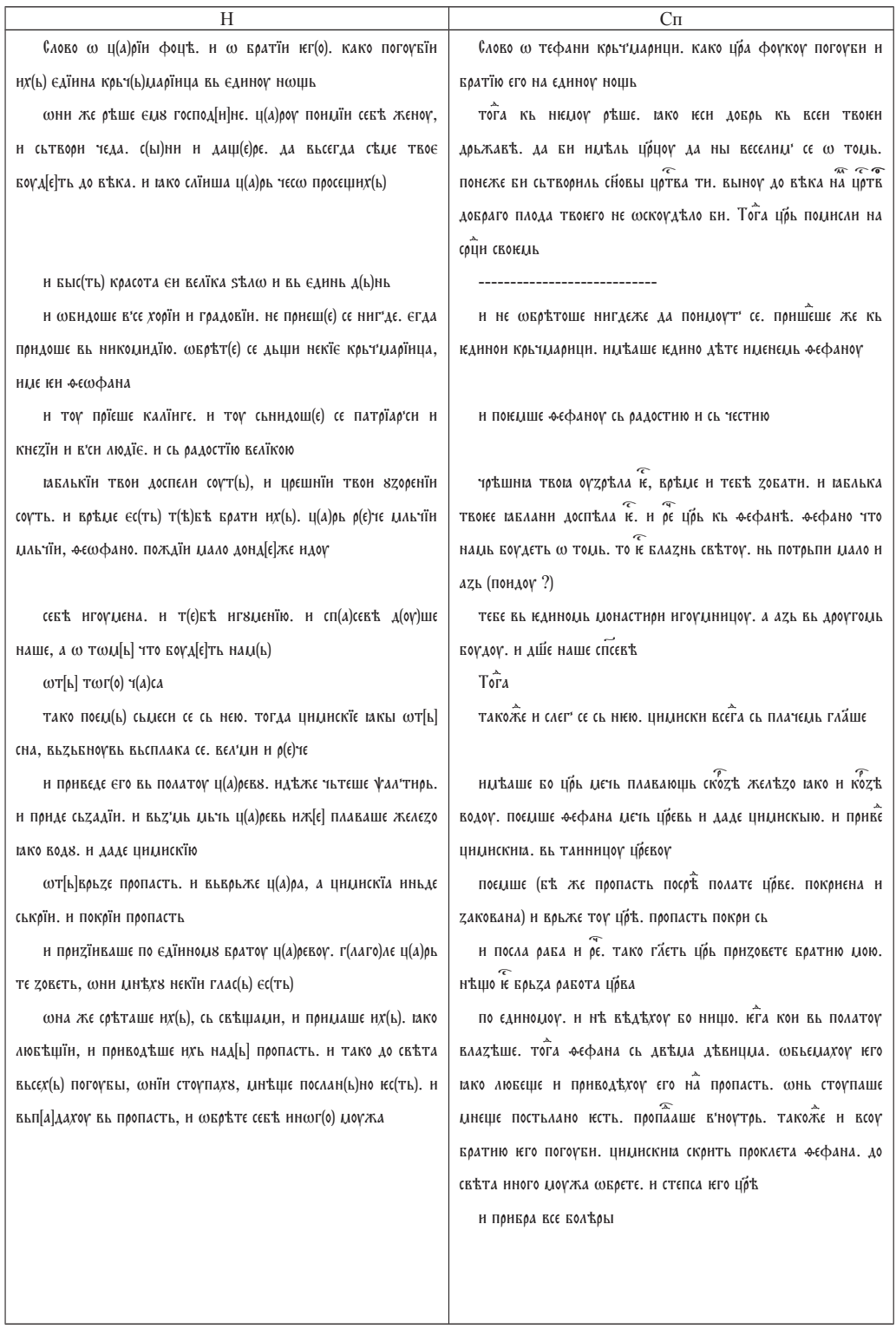




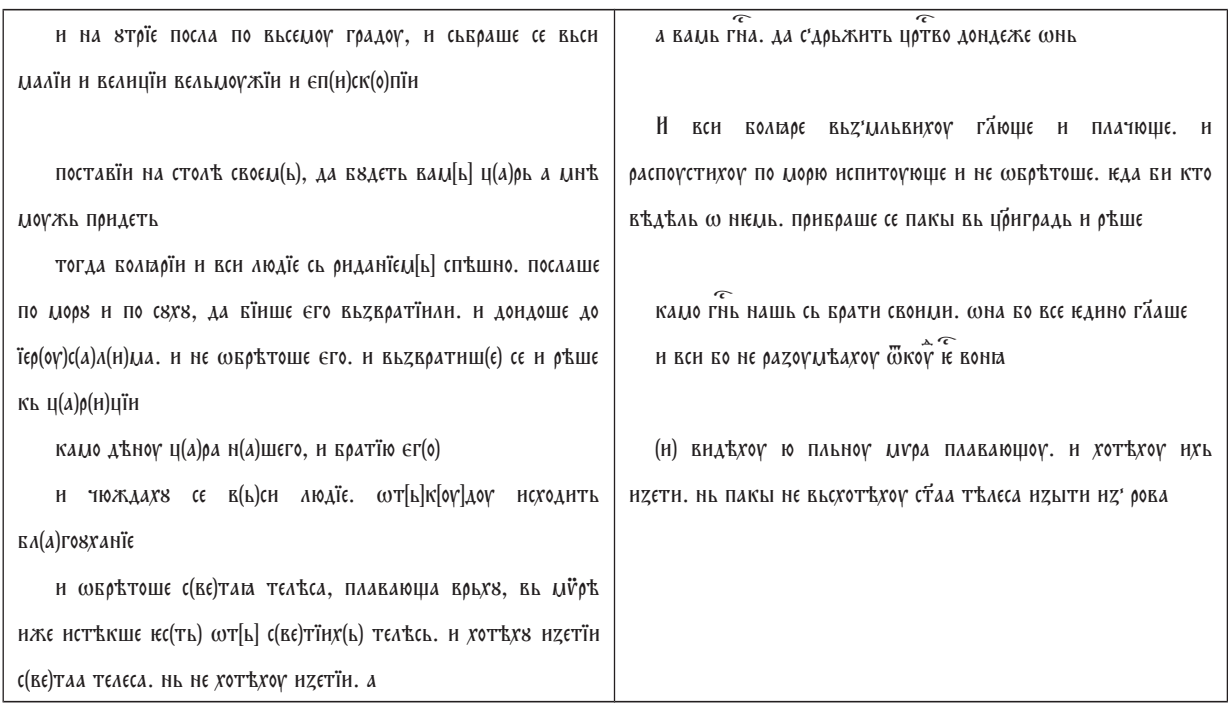

За разлику од текстова прва три преписа четврти се разликује језички по томе што је у њему извршена српска вокализација полугласника у јаком положају вокалом $a$. Тако се срећемо са речима како су се иначе према српскословенском читању изговарале: вавржє, вадамъ, ваzамшн, вадврашв сє, ваZрасте, вападаху, васєГАа, васн, васнга, вахождаху, КА, КораБалъ, на (У значењУ него, али), са, саБрашє сє, сададн, сатворнтн, сатворшаго. Поред ове, доследно спроведене појаве, искрсавају неке црте народног језика. Тако се изоставља слово $x$ у речима нтростню и раБростню. Наспрам облика имена фока јавља се и варијанта са замењеним $\phi$ словом в: вока, што је иначе одлика појединих српских народних говора. Уместо српскословенског облика прилога zat срећемо варијанту т४н из народног језика. Необично је такође што се једино у овом препису поред словенске речи рат (наєАн сє юхь ратню) јавља и грчка реч полем (ло́ $\lambda \varepsilon \mu о \varsigma)$ у изразу наснтнтн сє полєща.

Мада сачувана у скромном обиму, српска рукописна традиција приповетке о крчмарици Теофани и убиству цара Фоке показује богату варијантност, која је проистекла из стваралачке тежње појединих писара, који нису били само пуки преносиоци затечених предложака у нове преписе, него и спремни да понегде преуреде и измене токове казивања. Уосталом, то је са књижевне стране значајна текстолошка иновација, а уношењем речи из личног говора писара награда за сваког проучаваоца. 
У додатку доносимо приређена издања два до сада необјављена преписа. Један је из рукописне збирке манастира Никољца број 82, уз поређења са преписима Сп и На. Други приређени препис узет је из рукописа збирке Патријаршијске библиотеке у Београду са сигнатуром 343.

\section{ЛИТЕРАТУРА}

Башић 1931: Из старе српске књижевности, превео и саставио Миливоје М. Башић, Четврто, исправљено и нешто допуњено издање. Београд: Издавачка књижарница Геце Кона, 43-46; Из наше књижевности феудалног доба.

Ђурић 1976: И. Ђурић, Породица Фока, Зборник радова Византолошког института, XVII, Београд, 189-296.

Јовановић 2000: Стара српска книжевност. Хрестоматија, приредио и превео Т. Јовановић, Београд: Филолошки факултет; Крагујевац: „Нова светлост”, 412.

Јовановић 2012: Хрестоматија средњовековне књижевности, том I, Старословенска и преводна књижевност, приредио и на савремени српски пренео Т. Јовановић, Београд: Филолошки факултет, Библиотека Српска књижевност (Коло Стара српска књижевност, књига I, 294).

Каган 1989: М. Д. Каган, Слова о добрых и зльх женах, Словарь книжников и книжности Древней Руси, вып. II (вторая половина XIV-XVI в.), часть 2, Л-Я, АН СССР, Ленинград: Институт Русской литературы (Пушкинский дом), „Наука”, 399-401.

Крсмановић, Џелебџић 2010: Б. Крсмановић, Д. Џелебџић, Јован Цимискије и Нићифор II Фока: позадина и мотиви једног убиства с предумишљајем, Зборник радова Византолошког института, XLVII, 83-120.

Мечев 1975: К. Мечев, Възмездие за жестокостта: Към въпроса за идейната характеристика и времепоявата на средневековния български апокрифен разказ за убийството на византийския император Никифор Фока от кръчмарката Теофана, Литературна мисъл, 2. София, $115-136$.

Милтенова 1992: А. Милтенова, Кръчмарката Теофана, Старобългарска литература. Енциклопедичен речник, „Петър Берон”, София. 245-246. 
Милтенова 1994: А. Милтенова, Цикъл разкази за злите жени в сборниците със смесено съдържание през Средновековието, Старобългарска литература, 28-29, 131-136.

Начов 1892: Н. А. Начовъ, Тиквешки рхкописъ, Сборникъ за народни умотворения, наука и книжнина, VIII, София.

Салмина 1989: М. А. Салмина, Повесть о Никифоре Фоке, Словарь книжников и книжности Древней Руси, вып. II (вторая половина XIV-XVI в.), часть 2, Л-Я, АН СССР, Институт Русской литературы (Пушкинский дом), „Наука”, Ленинград, 255-256.

Сирки 1883: Сырку, Византійская повъсть объ убіеніи императора Никифора Фоки въ стариномъ болгарскомъ пересказъ, Санктпетербургъ.

Сперански 1898: М. Сперанскій, Замътки о рукописяхъ Белградскихъ и Софійской библіотекъ, Извъстія Историко-филологическаго Института князя Безбородко въ Нъжинъ, XVI, Москва, 57-59; Превод овог преписа у: Стара српска къижевност. Хрестоматија, 411-414; Хрестоматија средњовековне књижевности, том I, 293-296.

Турдеан 1976: É. Turdeanu, Le dit de l'empereur Nicéphore II Phocas et de son épouse Théophano, Thessalonique.

Павловић, Маринковић 1959: Из старе српске књижевности, друго допуњено издање, избор, редакција, превод и коментари Д. Павловић и Р. Маринковић, предговор Д. Павловић, Сарајево: „Свјетлост”. [Треће и четврто издање: Београд: „Просвета”, 1975, Библиотека Просвета, књига 102], 203-205. 
Томислав Ж. Йованович

СЛОВО О НИКИФОРЕ ФОКЕ И КОРЧМАРКЕ ФЕОФАНЕ

\section{Резюме}

Византийский император Никифор II Фока правил с 963 по 969 год. Его убил Иоанн Цимисхий, который и занял престол. Считают, что Цимисхию в этом оказала содействие супруга Фоки Феофана. Это событие описано в греческих летописных и историографических сочинениях Льва Диакона, Михаила Пселла, Иоанна Скилицы и Иоанна Зонары. В конце XII - начале XIII века возникла повесть на греческом языке, где убийство царя Фоки представлено в художественном преломлении. Повесть во многом удаляется от исторической основы, но при помощи воображения, характерного для литературного оформления, в нее вводятся факты, приближающие ее к сюжетам фольклорного повествования. Известны сербские списки краткого и пространного варианта повести.

Ключевые слова: император Фока, Феофана, убийство, сербские списки, издание текста. 
Манастир Никољац, број 82, 1515/1520. година, 66б-70б

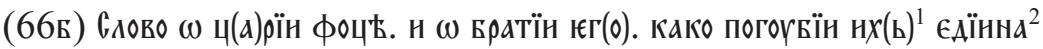
крьт(ь)щарїнца вь ${ }^{3}$ єднноү н(щь

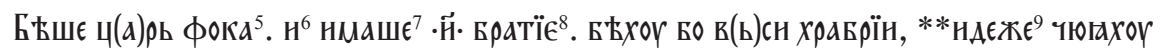

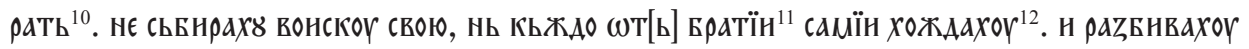

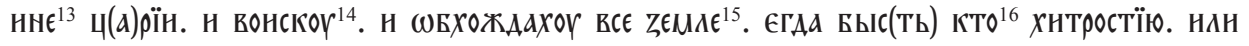

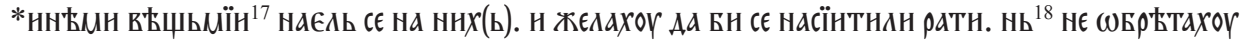

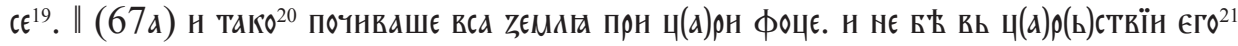

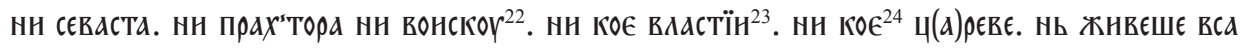

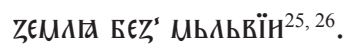

${ }^{1} \mathrm{Ha}-1$

${ }^{2} \mathrm{Ha}+(ж) \epsilon$ на.

${ }^{3}$ Сп: Слово $\omega$ тєфанн крьт'марнци. како цра форкоү погоүвн н Братїю єГо на.

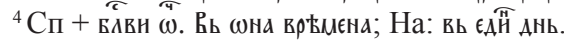

${ }^{5}$ Сп: форка.

${ }^{6} \mathrm{Ha}-1$.

${ }^{7}$ Сп: нмњгашє.

${ }^{8}$ Сп: вратєн, + свонхь.

${ }^{9}$ На: гдћ.

${ }^{10} \mathrm{Ha}$ : ратн.

${ }^{11} \mathrm{Hа:} \widetilde{0}$ вратніє.

${ }^{12} \mathrm{Ha}$ : самь сн хождашє.

${ }^{13} \mathrm{Ha}-1$

${ }^{14} \mathrm{Hа:} \mathrm{вонскн.}$

${ }^{15} \mathrm{Ha}$ в всог zемлю.

${ }^{16} \mathrm{Ha}-1$.

$17 *$ На: зиовомь.

${ }^{18} \mathrm{Ha}:$ н.

${ }^{19} \mathrm{Ha:} \mathrm{н.}$

${ }^{20} \mathrm{Ha}:$ така.

${ }^{21}$ На: вь неговЊ црґсттвђ.

${ }^{22} \mathrm{Hа:} \mathrm{нн} \mathrm{вонске.}$

${ }^{23}$ На: вонске.

${ }^{24} \mathrm{Ha}-2$.

${ }^{25}$ На: ветьми'вно.

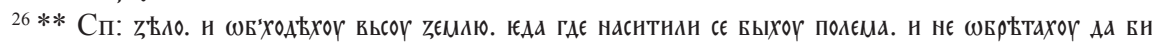

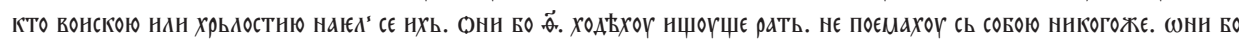

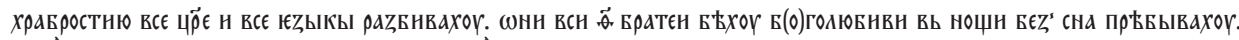

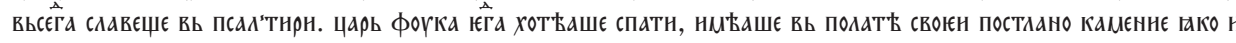

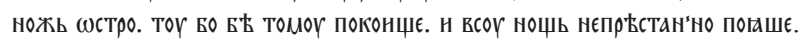




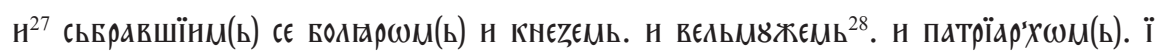

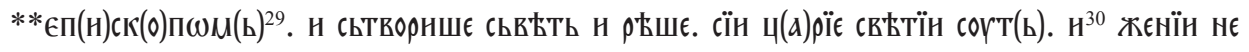

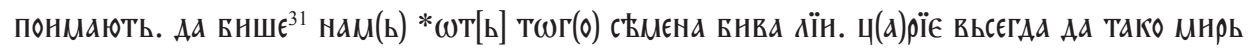

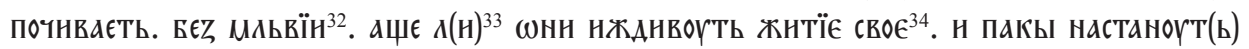

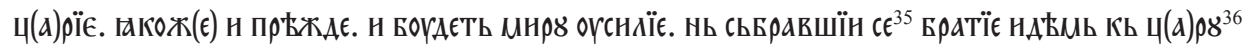

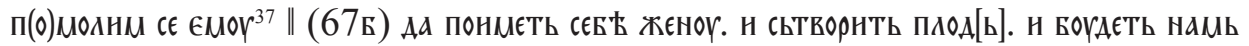

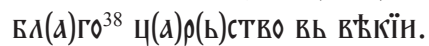

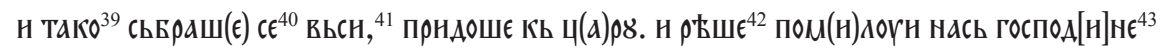

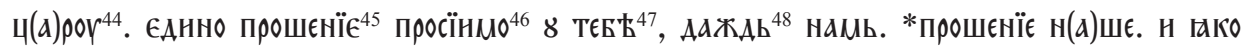

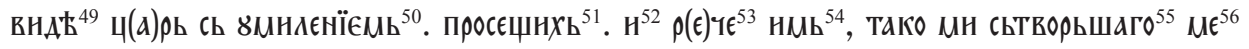

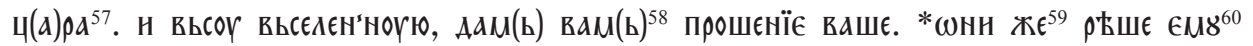

${ }^{27} \mathrm{C}$ П, На -1 .

${ }^{28}$ Сп: воющь.

${ }^{29} \mathrm{Hа:} \mathrm{єпйкоүпїє} \mathrm{н} \mathrm{патрнгарсн.}$

${ }^{30} \mathrm{Ha}-1$.

${ }^{31} \mathrm{Hа:} \mathrm{вн.}$

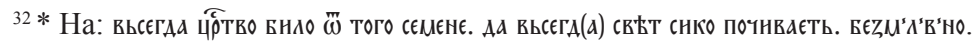

${ }^{33} \mathrm{Ha}-2$.

${ }^{34} \mathrm{Ha} \leftrightarrow$.

${ }^{35}$ На: сьеєрете ce.

${ }^{36} \mathrm{Ha}+{ }_{\text {Ad. }}$

${ }^{37} \mathrm{Ha}:$ црр.8.

${ }^{38} \mathrm{Hа:} \mathrm{нБлг्厂} \mathrm{о์ттно.}$

${ }^{39} \mathrm{Ha}-1$.

${ }^{40}$ На: прнгра сє.

${ }^{41}$ На: вса zємла н.

$42 * *$ СП: патрнархомь н прндошє Кь цр̈ю фоүц' н гйашє ємог.

${ }^{43} \mathrm{Cп}$ : ге, + помйоүн на.

${ }^{44} \mathrm{C}_{\Pi}-1$.

${ }^{45}$ На: прощєнїє.

${ }^{46}$ Сп: просниь.

${ }^{47}$ Сп: 3, 1, 2.

${ }^{48} \mathrm{C}$ п, На: дан.

${ }^{49} \mathrm{Ha}: \stackrel{x}{\text { н. }}$.

${ }^{50}$ На: радостню.

${ }^{51} \mathrm{Ha}:$ просещє ${ }_{\mathrm{H}}$.

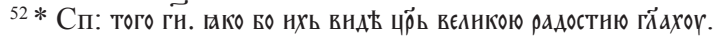

${ }^{53} \mathrm{C} \Pi+\kappa ь$.

${ }^{54} \mathrm{C}$ П + сь zаклетніемь; На -1.

${ }^{55} \mathrm{C}$ : сьтворнвн.

${ }^{56}$ Сп: на; Н На -1.

${ }^{57} \mathrm{C} \Pi-1$; На: црр $\mathrm{k} x$.

${ }^{58} \mathrm{C} \Pi-1$.

${ }^{59} \mathrm{Ha}-1$.

${ }^{60} \mathrm{Ha}-1$. 


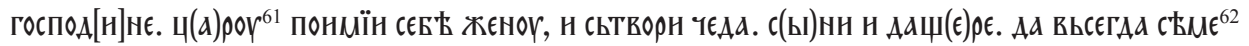

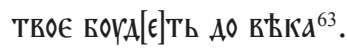

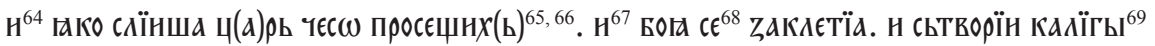

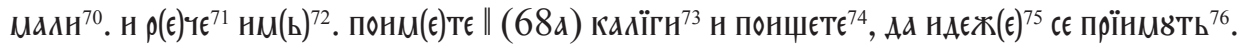
то ${ }^{77}$ прнв $[\epsilon]$ АєТ

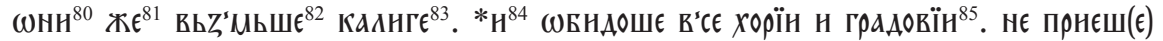

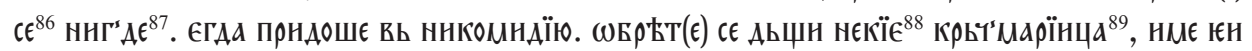

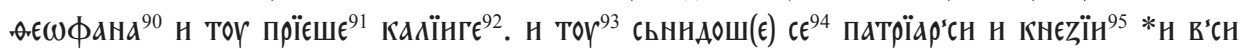

${ }^{61} \mathrm{Ha}-1$.

${ }^{62} \mathrm{Ha:} \mathrm{церство.}$

${ }^{63} \mathrm{Ha}: 2,3,1$.

${ }^{64} \mathrm{Ha}-1$.

${ }^{65}$ На: прошахог.

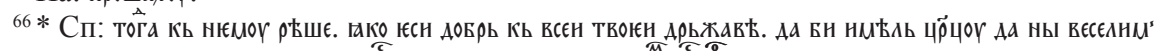

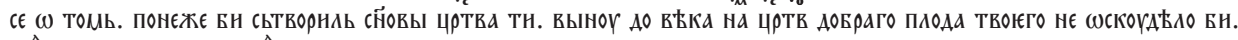
ТоГ̆ ц

${ }^{67} \mathrm{Ha}-1$.

${ }^{68} \mathrm{C}$ П, На: оүвог сє.

${ }^{69}$ СП: калнгнне, + вєлнко тьсны н; На: калнге.

${ }^{70} \mathrm{Ha}:$ masє.

${ }^{71} \mathrm{C} \Pi+\kappa \mathbf{~}$.

${ }^{72}$ Сп: ннмь.

${ }^{73}$ Сп: калнгнє; На: калнге.

${ }^{74} \mathrm{C}$ п, На -2 .

${ }^{75}$ Сп: гдє; На: єГда.

${ }^{76} \mathrm{C}$ П, На $\leftrightarrow ; \mathrm{C \Pi}^{+}$калнгнє.

${ }^{77} \mathrm{Hа:} \mathrm{на} \mathrm{ногог.}$

${ }^{78} \mathrm{Ha:}$ мн тон.

79 * Сп: Хощеть Бытн вамь.

${ }^{80} \mathrm{C} \Pi-1$.

${ }^{81}$ Сп: н; На -2.

${ }^{82}$ Сп: поєешш; На: прнємшє.

${ }^{83} \mathrm{C}$, На: калнгїє.

${ }^{84} \mathrm{Ha}-1$.

${ }^{85}$ На: градовь, + н.

${ }^{86}$ На: не прнехоү сє.

${ }^{87} \mathrm{Ha}: 4,1,2,3$.

${ }^{88} \mathrm{Hа:} 8$ єдннон.

${ }^{89}$ На: кр'чм’'цा'.

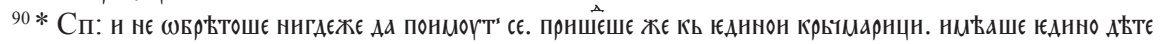
HМенеMь өефаноY.

${ }^{91} \mathrm{C}$, На: прнетог сє.

${ }^{92}$ Сп: калнгнц; На: калнге.

${ }^{93} \mathrm{Ha}-1$.

${ }^{94} \mathrm{C}$ П: сьнндохог сє.

${ }^{95}$ Сп: кнєZы н вонє; На: $3,2,1$. 
Аюдїє. н сь радостїю вєАїкою

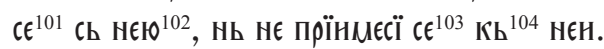

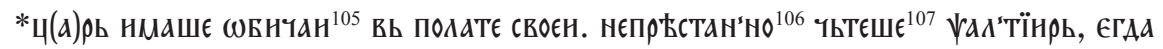
ХотЊш ${ }^{108}$ почннутн. нМашє ${ }^{109}$ каменїе

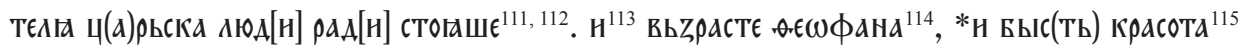

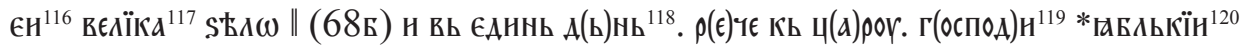

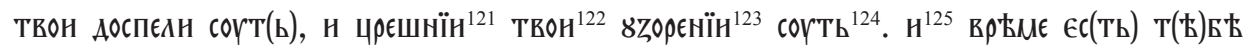
Братн нХ(ь $)^{126}$.

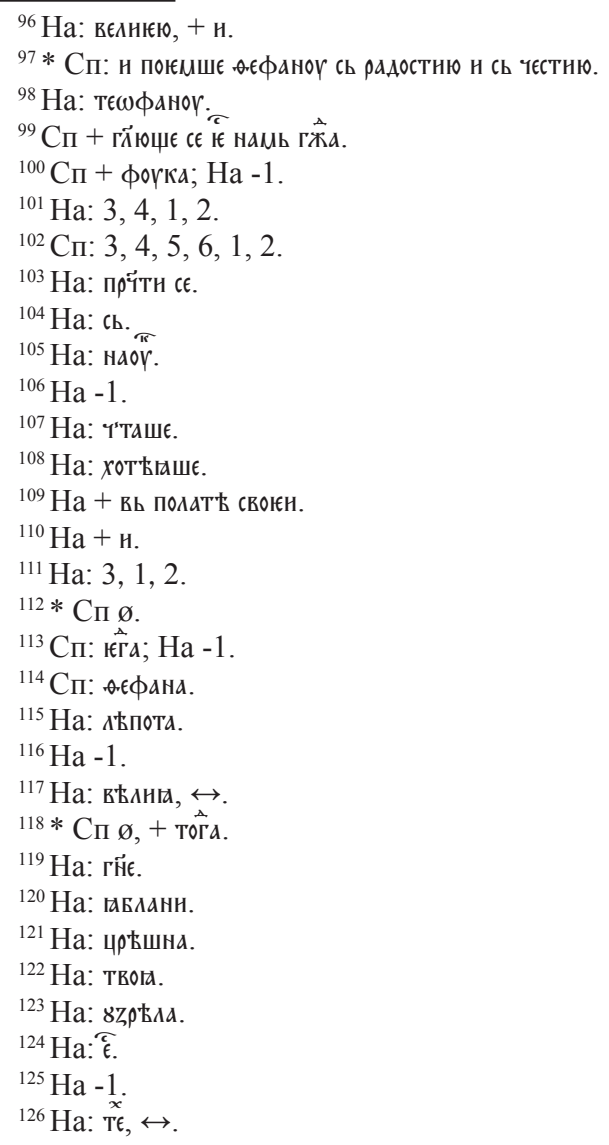




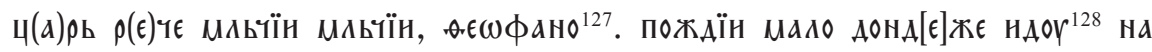

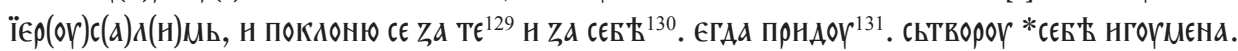

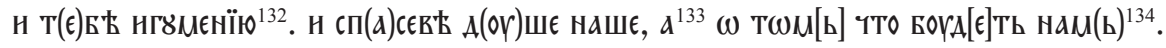

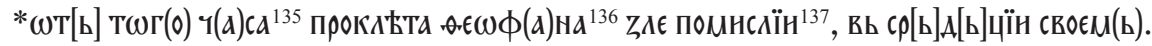

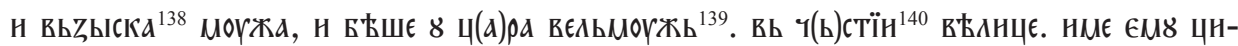

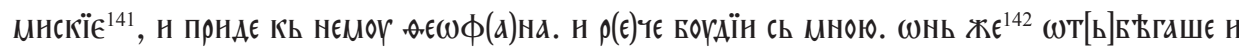

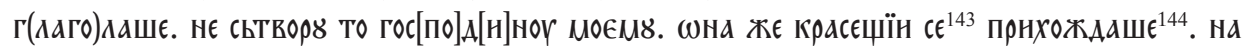

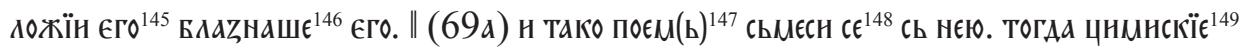

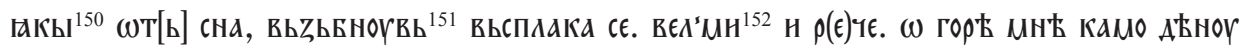

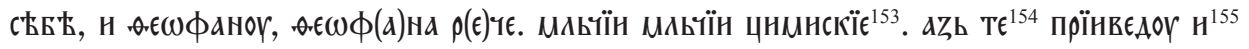

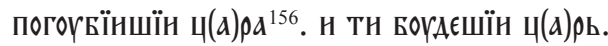

${ }^{127} \mathrm{Ha:}$ тєєфана, $\leftrightarrow$.

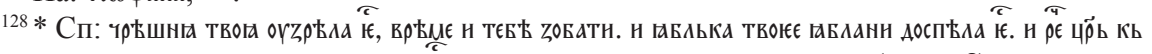

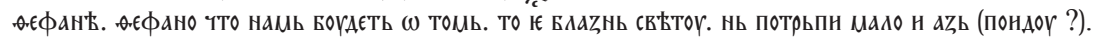

${ }^{129}$ На: тев

${ }^{130}$ Сп, На: 4, 5, 1, 2, 3, + н.

${ }^{131}$ Сп, На: вьzвращог сє.

${ }^{132}$ На: нгоүменнцц.

${ }^{133} \mathrm{Ha}-1$.

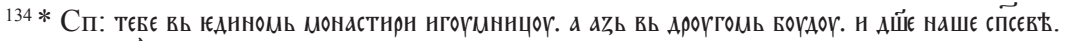

$135 *$ Сп: Тога

${ }^{136}$ Сп: н.

${ }^{137}$ На: помнслн помнс'Аь zьль.

${ }^{138} \mathrm{Ha}+$ сєЕь.

${ }^{139} \mathrm{На:} \mathrm{чйвкь.}$

${ }^{140} \mathrm{Ha}:$ мरтTн.

${ }^{141} \mathrm{Ha:} \mathrm{чнмнскн.}$

${ }^{142} \mathrm{Ha}-1$.

${ }^{143} \mathrm{Ha}+$ гА⿱̊шє.

${ }^{144} \mathrm{Ha}$ прнходе.

${ }^{145} \mathrm{Ha}$ : н.

${ }^{146} \mathrm{Ha:} \mathrm{вдажнашє.}$

${ }^{147} \mathrm{Ha}-1$.

${ }^{148} \mathrm{Ha}:$ сьлєжєш сє.

${ }^{149}$ На: чнинскй.

${ }^{150} \mathrm{Ha}$ : ґкко.

${ }^{151}$ На: вьспренув сє, + н.

${ }^{152} \mathrm{Ha}-1$.

${ }^{153} \mathrm{Ha:} \mathrm{чнинскннє.}$

${ }^{154}$ На: тєв

${ }^{155} \mathrm{Ha}+$ TH.

${ }^{156} \mathrm{Ha}$ : црї. 


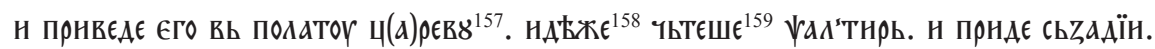

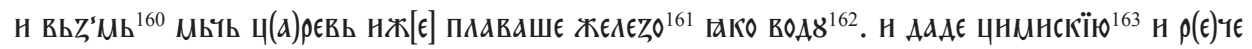

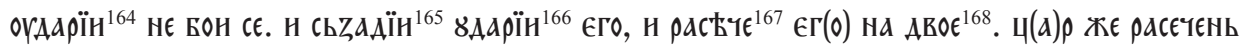

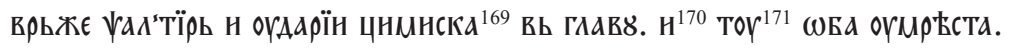

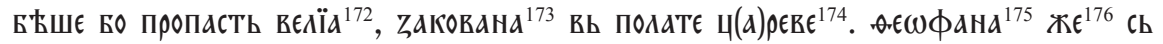

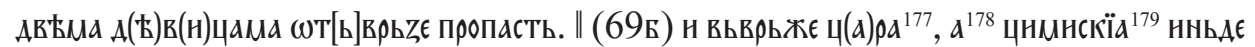
ськрїн. н покрїн пропасть. сковЊр

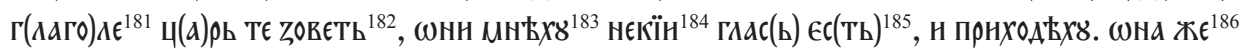

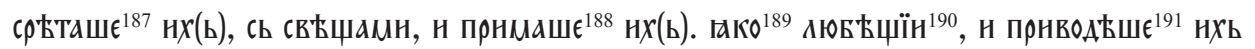

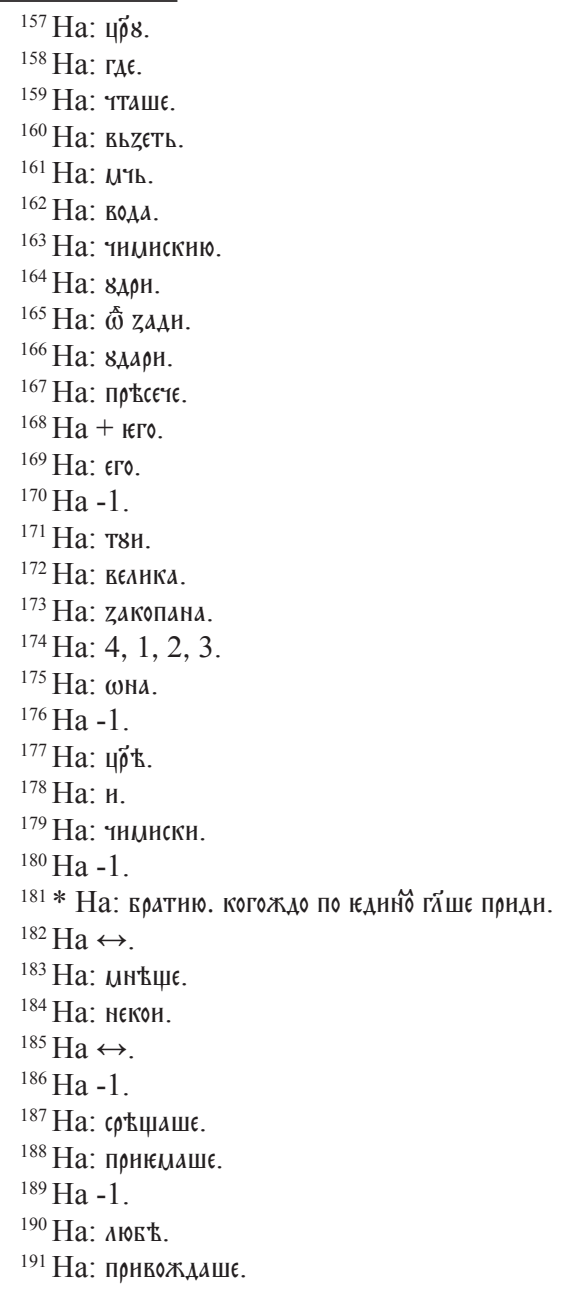




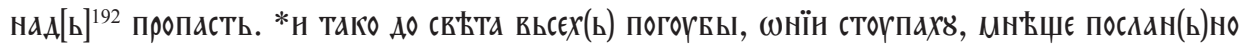

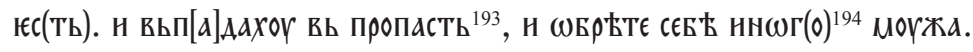

н на 8трїє $\epsilon^{195}$ посла ${ }^{196}$ по вьсємоү градог, н сьБрашє сє $\epsilon^{197}$ вьсн ${ }^{198}$ Малї̈н н вєАнціїн ${ }^{199}$

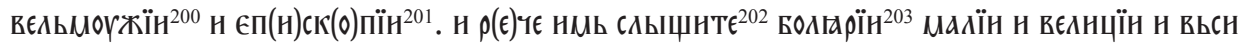

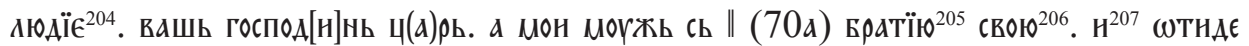

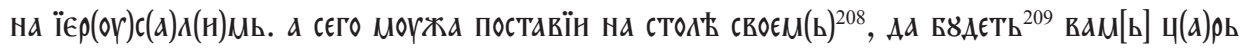
а мнњ могжь.

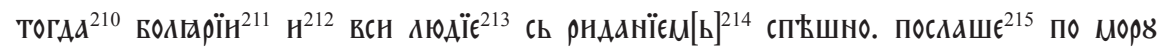

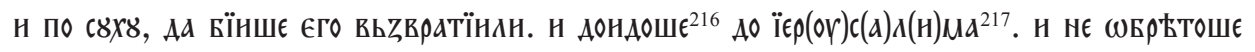

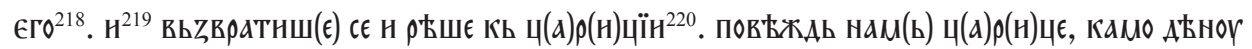

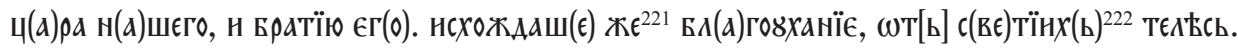

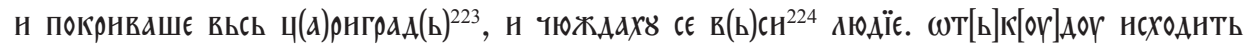

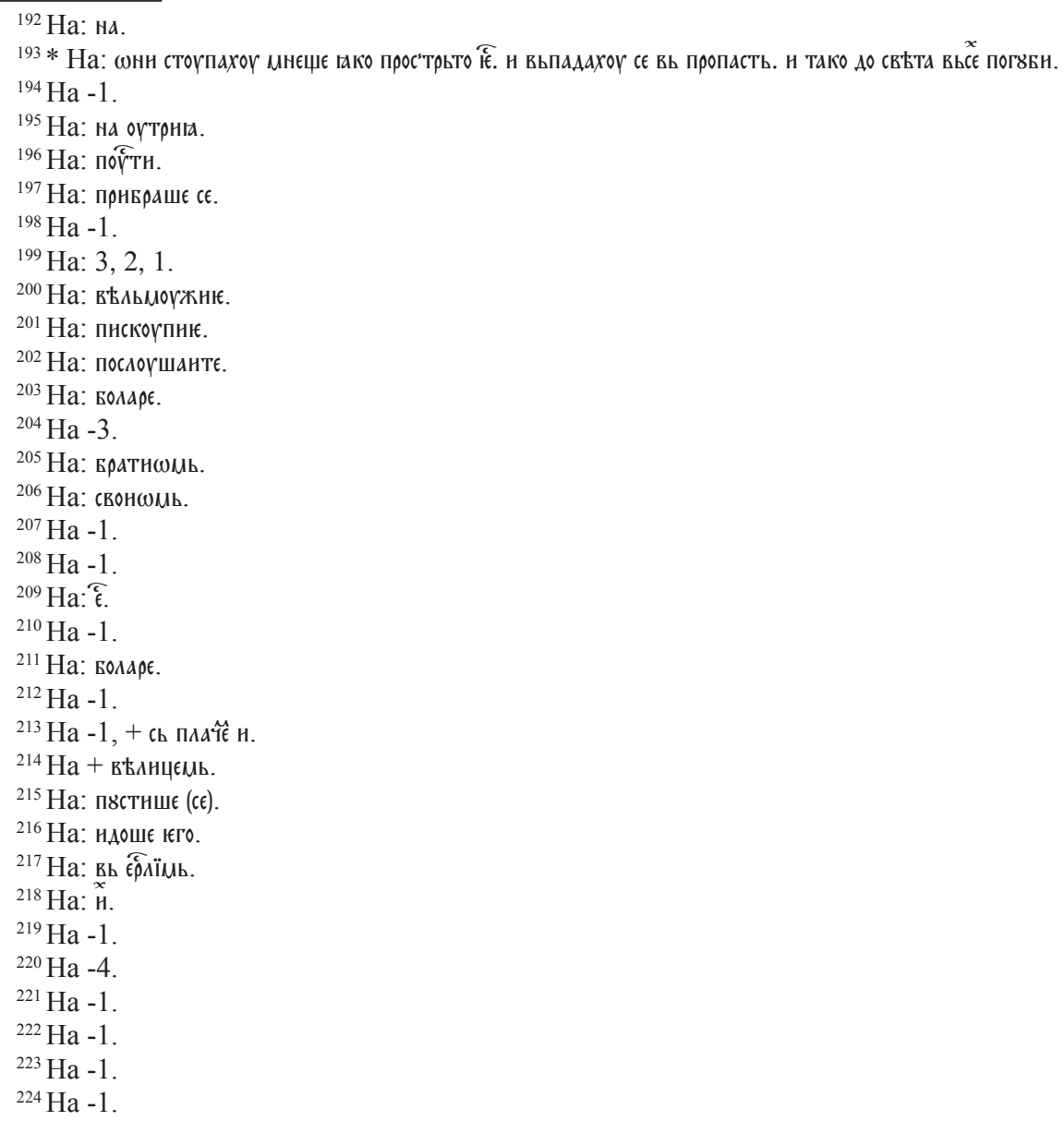




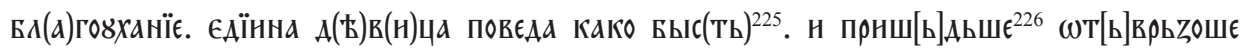
пропасть. н ФБрьтошє ${ }^{227}$ с(вє)таға тє

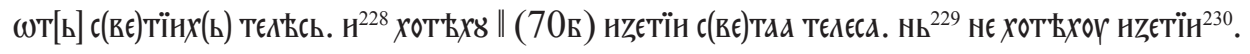
а Проклетон өєє)фанє чрЂва растої̈шє по градог.

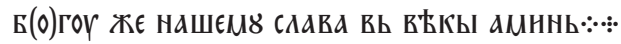

\section{Патријаршијска библиотека у Београду, број 343, последња четвртина XVII века, 451a-454a}

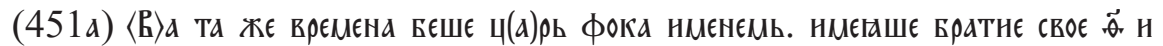
воН БєХУ васн $\because$ Н

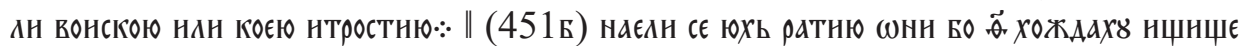

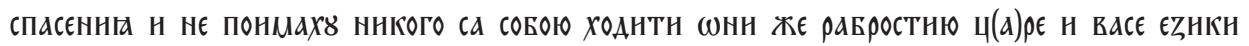
нұБнБах8

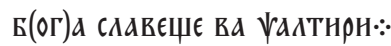

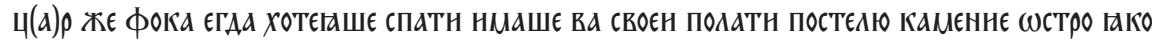

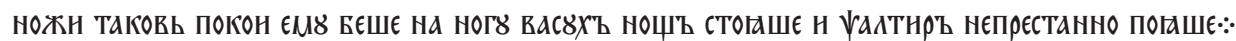

СаБравшнМ сє БолюароМъ н кнеZоМъ н патрнархоМъ н єпнскупоМъ н прндошє Ка ц(а)р૪

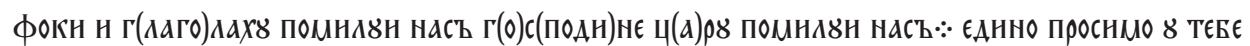

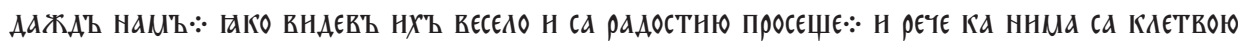

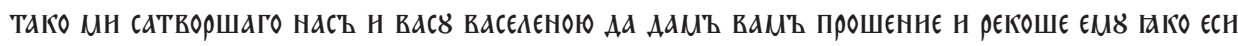

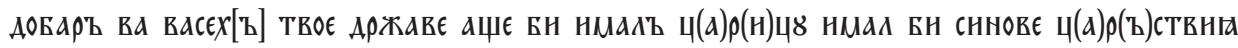

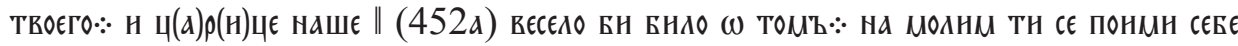

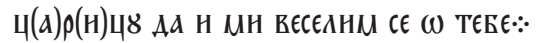

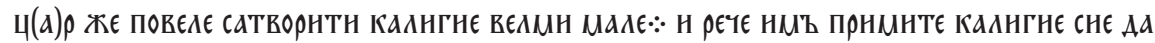

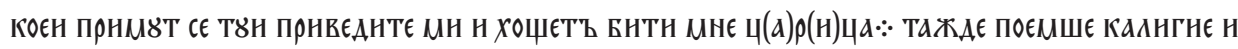

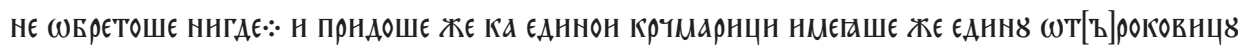

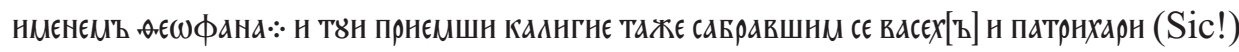

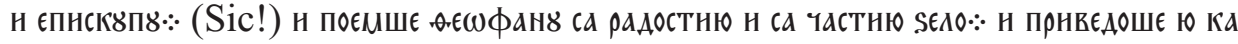

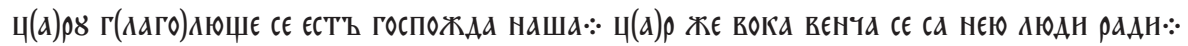

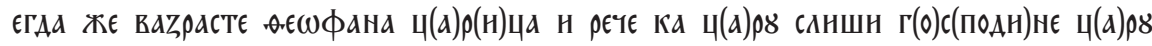

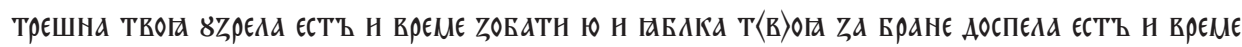

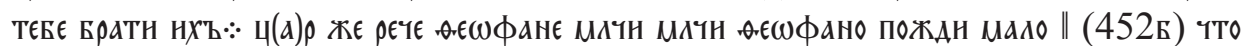

\footnotetext{
${ }^{225} \mathrm{Ha}-2$

${ }^{226}$ На: прндоше, + н.

${ }^{227}$ На: вндьшє.

$228 *$ На ø.

${ }^{229} \mathrm{Hа:} \mathrm{н8.}$

${ }^{230} \mathrm{Ha:} \mathrm{нднтн.}$
} 


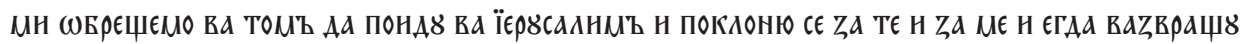

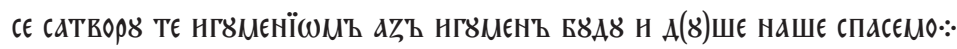

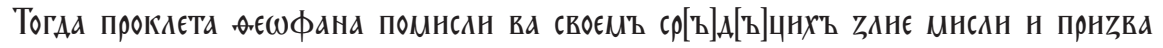
ЄАННОГО РАБа НМЕНЕМЪ ЦНННСКНЮ

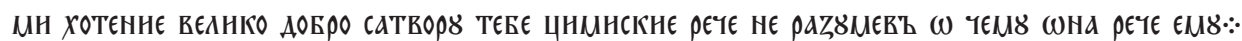

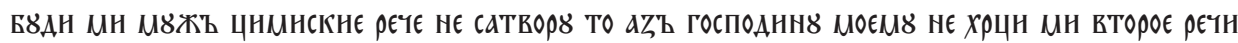

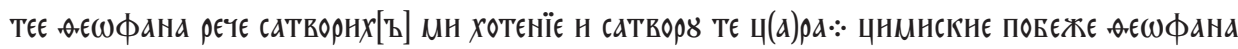

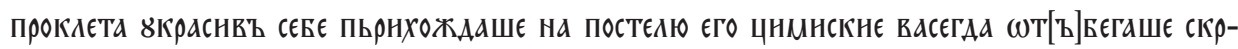

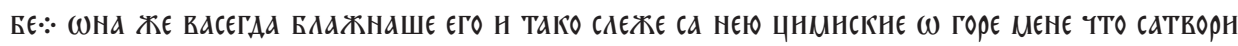

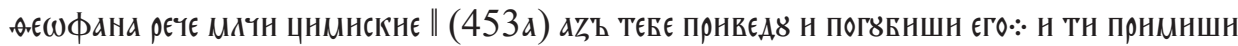

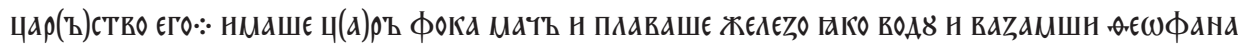

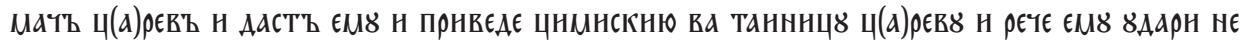

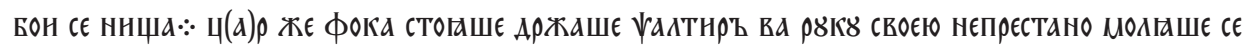

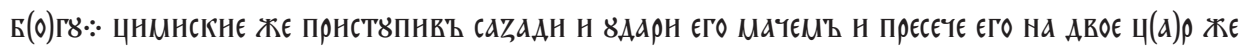

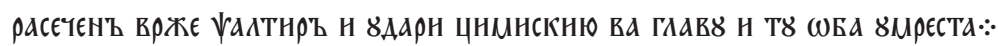

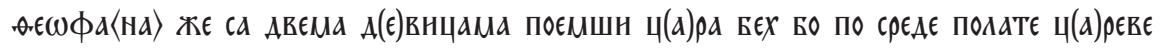
пропастъ н

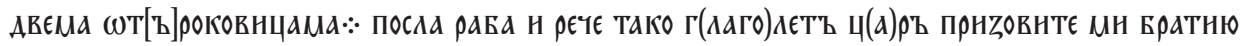

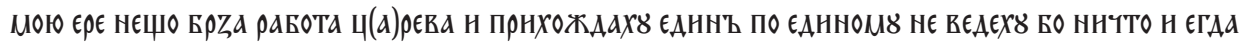

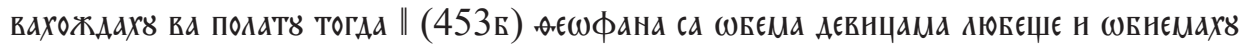

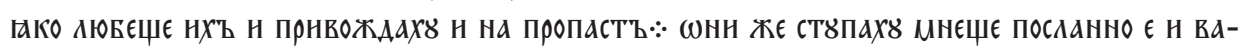

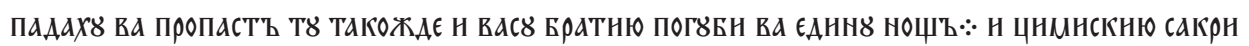

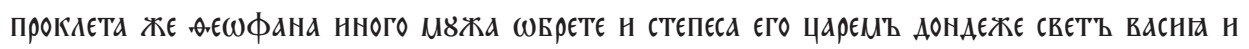

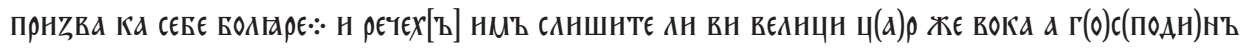

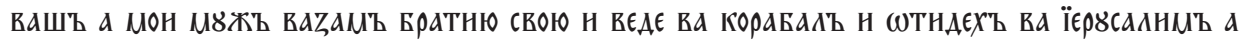

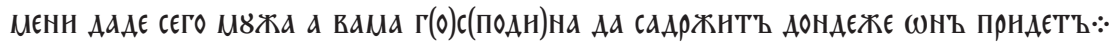

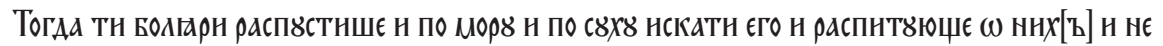

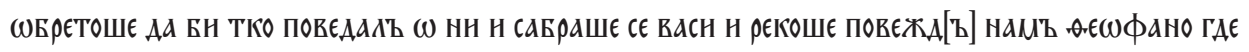

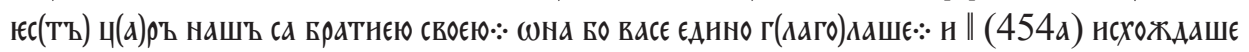

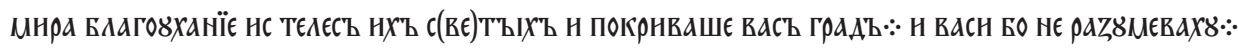

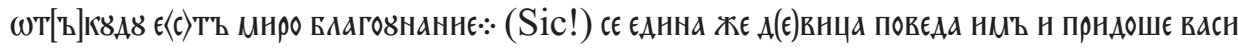
Болгарє н кнєZн н патрнхарн (Sic!) н єПнскУПн

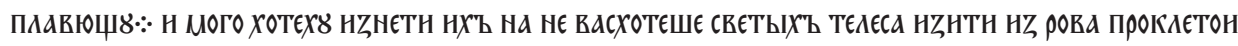

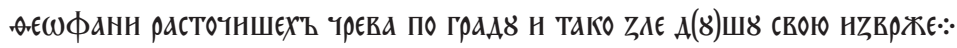

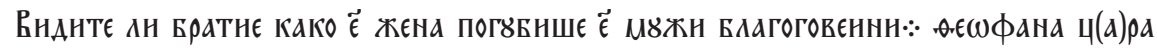

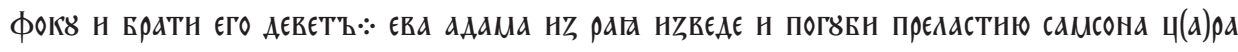

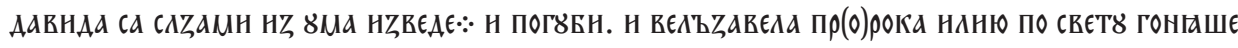

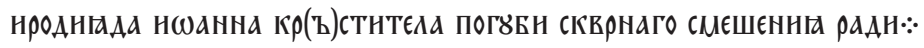

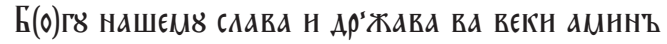

